\title{
Making the Transition from Conventional to Organic Farming Using Conservation Tillage in Florida ${ }^{1}$
}

\author{
Tawainga W. Katsvairo, David L. Wright, Jim J. Marois and Pawel P. Wiatrak ${ }^{2}$
}

Organic farming is one of the fastest-growing segments of agriculture in the U.S. and in Florida. Making the transition from conventional (strip till using genetically modified crops) to organic farming does not have to be filled with obstacles. National Organic Standards can be found on the National Organic Program web site at http://www.ams.usda.gov/nop. Even though there are many advantages to organic farming, it is a business and there are ways to get started that can ensure success. Organic farmers use only non-synthetic products for organic production. This is believed to assure environmental stewardship while offering food and fiber free of many chemicals that are commonly used in commercial food production. Organic growers usually receive a substantial premium for their products and have a unique niche market in many areas of the country. This transitioning does pose challenges to growers. The transition must be carried out correctly, or the consequences can negate the potential advantages of organic farming, making the operation much more difficult and in some cases unprofitable.
For many row-crop farmers who have been growing genetically-altered crops (i.e. Bt [Bacillus thuringiensis] and Roundup Ready crops) and using conservation tillage or no-tillage with cover crops, converting to organic crop production may seem like a step backwards in soil and water conservation and environmental stewardship. Organically certified materials often do not have the efficacy of newer pesticides with longer residual or more effectiveness, therefore, many more pesticide applications may be required. However, if small acreages of high cash-value crops are converted to organic production, areas can be chosen on the farm that will have minimum impact on the environment and may offer much higher profit potential. Many of the same techniques can be used with organic farming as with conventional farming operations, including conservation tillage and cover crops to control weed growth while protecting soil and conserving moisture. Cover crops can be managed by physical means such as using a roller (to roll down cover crops such as rye and oats when the stems have elongated to produce the seed head and hence kill the crop by breaking the

1. This document is SS-AGR-11, one of a series of the Agronomy Department, Florida Cooperative Extension Service, Institute of Food and Agricultural Sciences, University of Florida. Original publication date March 2006. Visit the EDIS Web Site at http://edis.ifas.ufl.edu.

2. T.W. Katsvairo, crop and soil scientist, North Florida Research and Education Center--Quincy, FL; D. L. Wright, professor, Agronomy Department, North Florida Research and Education Center--Quincy, FL; J. J. Marois, professor, Plant Pathology Department, North Florida Research and Education Center--Quincy, FL; P. P. Wiatrak, agronomist, North Florida Research and Education Center--Quincy, FL; Florida Cooperative Extension Service, Institute of Food and Agricultural Sciences, University of Florida, Gainesville, FL 32611.

The use of trade names in this publication is solely for the purpose of providing specific information. UF/IFAS does not guarantee or warranty the products named, and references to them in this publication does not signify our approval to the exclusion of other products of suitable composition.

The Institute of Food and Agricultural Sciences (IFAS) is an Equal Opportunity Institution authorized to provide research, educational information and other services only to individuals and institutions that function with non-discrimination with respect to race, creed, color, religion, age, disability, sex, sexual orientation, marital status, national origin, political opinions or affiliations. U.S. Department of Agriculture, Cooperative Extension Service, University of Florida, IFAS, Florida A. \& M. University Cooperative Extension Program, and Boards of County Commissioners Cooperating. Larry Arrington, Dean 
stem near the ground), planning for frost to kill the cover crop or choosing a cover crop that will mature prior to planting the cash crop.

Croplands can be certified as organic only after they have been free of non-organic pesticides or similar materials for a period of three years. This usually requires planning so that the soil will be fertile and as free of weeds and other pests as possible when organic production begins. There is a National List (see website above) of materials that can be used in organic production, and Florida Organic Growers (http://www.foginfo.org/) can provide information and advice to new growers on certification, fees, applications, inspection, and reporting. Like any other endeavor, talking with organic growers about the challenges that they have faced and how they met those challenges is beneficial to any new producer. Potential growers should investigate what crops can most easily be grown and marketed at a time of the year when pests are at low levels. Many growers start out with small acreage while still growing other crops with conservation tillage/conventional practices. This allows growers to test the waters and transition into organic farming while gaining valuable experience with problems and opportunities.

The major challenge in Florida during the transition stage is control of weeds, especially perennial weeds such as Bermudagrass, teaweed, tropical spiderwort and others that reseed readily. A common organic farming practice is to till the land, leave it barren and allow several generations of weeds to germinate, then till the land again. Growers often till the land as many as 3-6 times during a growing season to "eradicate" weeds and prevent reseeding before they start farming organically -- a "deal with it now and not worry about it in future" approach. This practice results in high levels of soil erosion and subsequent loss of organic matter from the fragile Florida soils (See Figure 1). Growers acknowledge soil erosion, but often prioritize weed control over soil conservation. This does not have to be the case if appropriate measures are taken to plant cover crops that will compete with weeds and build soil organic matter.

The importance of both healthy soil and effective weed control in organic farming cannot be

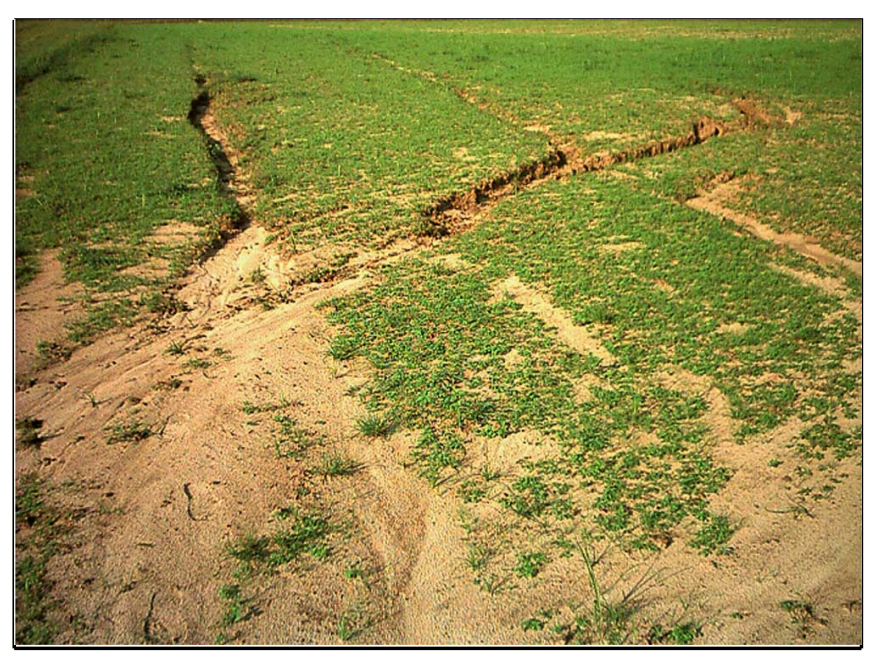

Figure 1. Consequences of tilling and leaving the land barren during periods of high rainfall.

over-emphasized. One of the underlying principles of organic farming is the building of healthy soils with good structure, high organic matter, diverse soil micro and macro fauna, and high water-holding capacity. Such soils can in turn support healthy plants which can better resist disease and insect and weed pressure (Organic Farming Research Foundation, 2003). Loss of nutrients and organic matter through erosion depletes soil fertility, and is further aggravated by the fact that synthetic fertilizer cannot be used in organic farming. Furthermore, sediment runoff water pollutes water bodies. The building of soil organic matter is a long-term process. Even when the best conservation measures are practiced, soil organic matter only increases at a rate of $0.1-0.2 \%$ per year (Martin, 2003). Thus proper management strategies to conserve organic matter are essential.

Management required for successful transitioning from conventional to organic farming varies with soil type, slope, drainage, fertility levels, weed species, disease concerns and the subsequent crop. Sandy soils are more prone to drought, while sloping lands are more prone to erosion (Figure 2). Tillage is often used as a way to bury weed seeds. Planting a mixture of grasses or grasses and leguminous crops immediately after tillage is suggested as a way to reduce potential erosion losses (Figure 3). An example of a good combination of grasses includes a mixture of millet and bahiagrass. Millet establishes very quickly and can prevent erosion during the early stages of succession. Bahiagrass is among the best adapted grasses for 
Florida. It is deep-rooted and can take up nutrients and recycle them from greater depths in the soil horizons. These nutrients would otherwise be lost. Bahiagrass has to be killed through tillage or smother crops. When bahiagrass dies, the roots decay and create channels in the soil profile which increase aeration and water infiltration. Bahiagrass grows well on less fertile soils and can out-compete encroaching weeds (Kalmbacher, 2003). Bahiagrass, however, takes longer to establish, hence planting it with millet or other faster-growing annuals is recommended. Once established, the millet can then be mowed or grazed, allowing the bahiagrass to dominate the mixture. Other grasses and leguminous plants can also be grown. Examples include soybean, annual ryegrass, and the small grains, all of which have aggressive-to-intermediate rates of establishment (Wright et al. 1978). Alfalfa can also be used, but like bahiagrass, it has a slow rate of establishment (Wright et al. 1978) and must be grown in conjunction with aggressive species to prevent erosion.

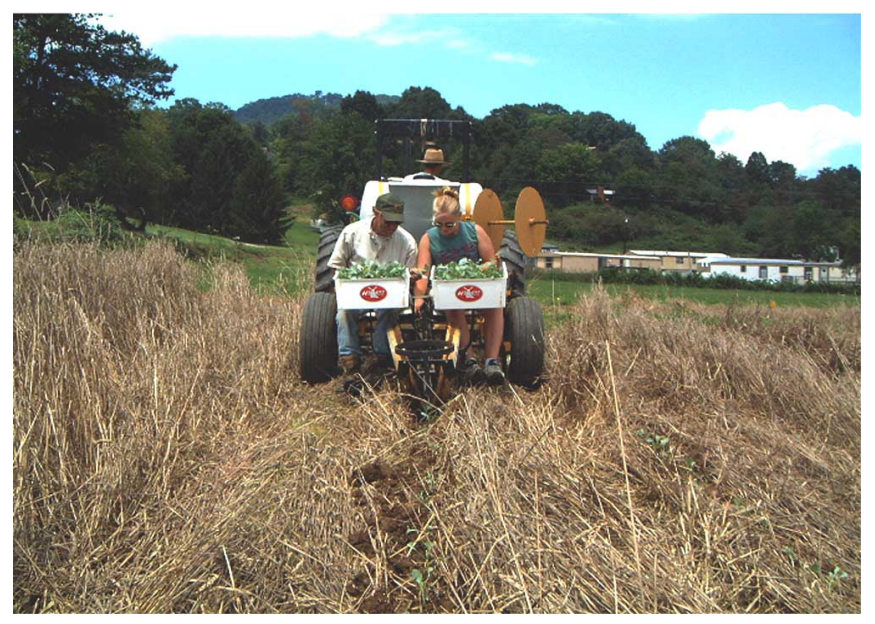

Figure 2. Cover crops control erosion on sloping land and no-till planting into residue. (Courtesy G. Hoyt)

Small-grain cover crops can be planted into bahiagrass late in the fall with some aggressive tillage. These small-grain crops can be rolled in the spring to smother the bahiagrass, and legumes (peas or beans) may be planted to recharge the soil nitrogen before another nitrogen-requiring vegetable is planted (Figure 4). Forage legumes can also be seeded with bahiagrass. This practice will add nitrogen to the soil. Both summer and winter legumes can be used. The legumes can be drilled into bahiagrass with a sod seeder or over seeded into bahiagrass after it has been

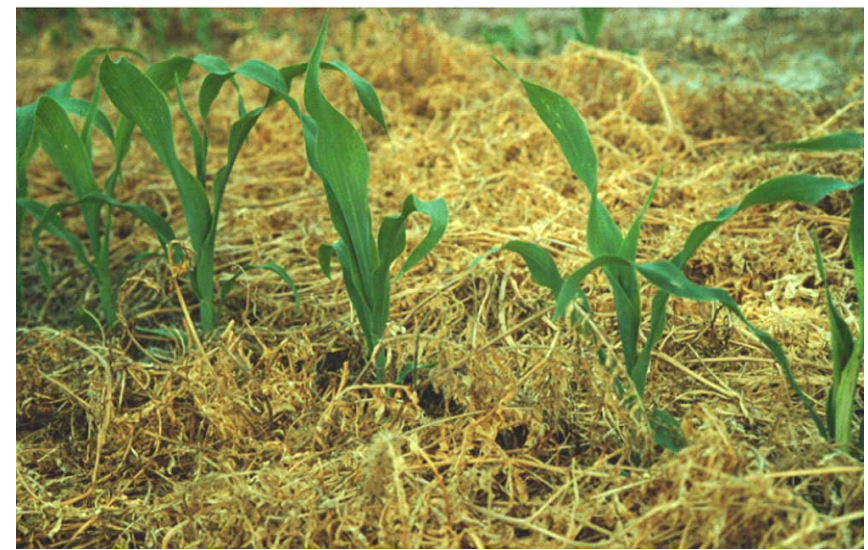

Figure 3. Corn in residue from the previous crop. Residues prevent soil erosion and preserve soil moisture.

chopped. Burning bahiagrass as a way to establish a good legume crop is not generally recommended because it results in loss of organic matter. It is a good idea for growers to consult their local county Extension agents or Extension forage specialist to select the adapted legumes, seeding rates and planting method. The seed mixtures should be chosen carefully depending on the time of year and plans for cropping. Our experiences have shown that tilling the field more than once during the growing season does not necessarily result in better weed control. Mixtures of grasses and leguminous plants discussed so far act as mulches in suppressing weeds. Other mulches, including plastic and organic mulches, can be used to suppress weeds.

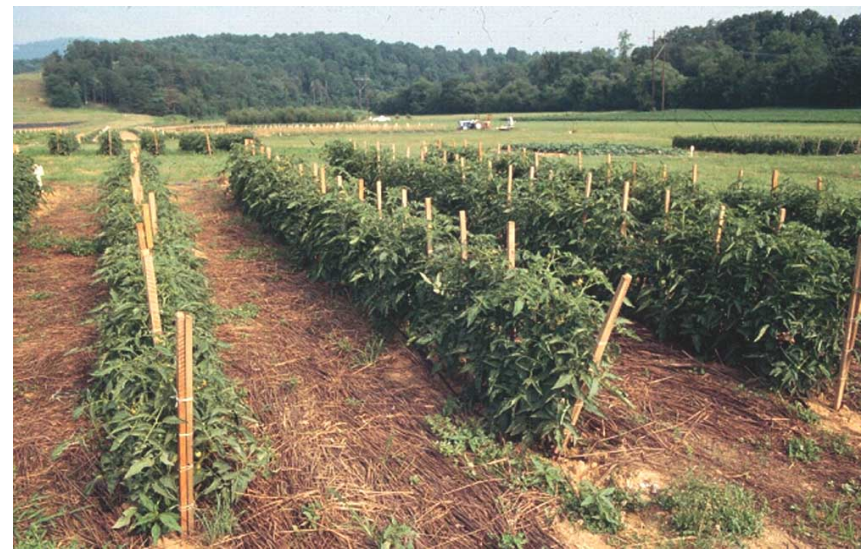

Figure 4. Tomato planted in a rolled cover crop. (Courtesy of G. Hoyt)

Although not limited to the transitioning stage alone, it may be essential to subsoil under the row as with strip tillage if the compaction layer has not been penetrated by roots of perennial grasses or if perennial grasses are not completely decomposed or 
not being used in the rotation. Sub-soiling into the compaction layer improves water infiltration, porosity, bulk density, soil crumb structure and results in better plant growth in the area of the subsoil pass.

Conservation tillage can still be used for organic farming if cover crops are chosen carefully and other techniques are used to ensure that cover crops do not compete with the crop being grown. Tilling the land multiple times during the growing season and leaving it barren is strongly discouraged. While it is more costly in the short term to till the land or use a no-till drill and plant cover crops compared to just tilling the land and leaving it barren, it should be kept in mind that a well-managed soil is a worthwhile investment with long-term returns. A healthy soil with high organic matter and good structure is indispensable. Organic matter should be viewed as a "revolving nutrient bank account" because it is a storehouse of plant nutrients which is released to plants upon decomposing. Hence loss of this "bank account" should be prevented (Agriculture, Food and Rural Development, 2003).

\section{Tips for Transitioning from Conventional to Organic Farming Practices}

- Select fields that have had adequate fertility and proper $\mathrm{pH}$ levels before beginning production.

- Select fields that have had a history of light weed pressure.

- Select fields with well-drained soils, adequate water-holding capacity and that have been well rotated so that diseases will not be a major concern.

- Plant cover crops that will grow vigorously prior to the crop but can be killed by rolling with a roller or naturally by frost or maturity prior to planting the organically grown crop.

- Soybeans or millet can be drilled late in the season and killed by frost, rolled or be killed with organic materials like sodium chlorate for a thick ground cover that may be planted into for fall crops (cole crops).
- Rye or oats can be planted early in the fall and killed by rolling with a roller after heading in the spring (late March) for a thick ground cover which will help control weeds and holds moisture for a spring crop (cole crops or other summer crops).

- Choose crops carefully for planting during a season that is relatively free of pests (cole crops may work well for a first crop planted in late August or in early March).

- Perform all operations in a timely manner.

- If irrigation is not available, choose crops that grow in a seasonal period when rainfall is adequate (the most consistent period for rainfall and moderate climate with few pests usually occurs from January through April).

- Apply composted chicken manure, mushroom compost or other types of weed free organic matter when available to keep soil fertile and increase organic matter.

- Use as little tillage as possible, since tillage destroys soil structure, causes erosion, reduces soil organic matter, and may result in lower yields. Strip-till rigs that only open a slit for row crops may be used for vegetables as well as other crops while suppressing weeds and conserving moisture. Tillage may be necessary on some perennial grasses but may still have adequate soil cover to slow erosion and maintain $30 \%$ or more ground cover while the crop is growing.

- Use perennial grasses (e.g., bahiagrass) in the rotation if possible, since weeds, disease, and nematodes are reduced and organic matter is increased to a greater extent with grasses rather than legumes. Yields of many crops have been shown to be higher after perennial grasses and are preferred by peanut, watermelon and other growers. Bahiagrass may have to be chisel plowed prior to planting a cash crop to reduce competition.

- If using legumes as cover crops, remember that they decompose quickly and may not protect the soil from erosion or prevent long term weed competition. 
- Find out about organic farming and markets for your products from those who have done it successfully before planting the crop.

\section{References}

Agriculture, Food and Rural Development. 2003.

Soil organic matter. Alberta Government.

http://www1.agric.gov.ab.ca/\$department/

deptdocs.nsf/all/agdex 890

Kalmbacher, R.S. 2003. Establishment of

legumes in bahiagrass sod.

http://www.ag.auburn.edu/nsdl/sctcsa/

Proceedings/1980/Kalmbacher.pdf

Martin, H. 2003. Transition to organic farming.

Ministry of Agriculture and Food. Ontario.

Online:

http://www.omafra.gov.on.ca/english/crops/

organic/transition.htm

Organic Farming Research Foundation, 2003.

How do organic farmers fertilize and control

pests, diseases, and weeds? Online:

http://ofrf.org/resources/organicfaqs.html

Wright, D.L, R.E. Blaser, and J.M. Woodruff.

1978. Seedling emergence as related to

temperature and moisture tension. Agronomy

Journal. Vol. 70: 709-712. 